\title{
Approaching Land Cover-Land Use Changes Using Statistical Data Validation for Urban Policies Improvement
}

\author{
Maria-Ioana VLAD ȘANDRU1, 2, Corneliu IAȚU1, Daniel Cristinel ȘANDRU3, Daniela Gabriela \\ CIMBRU3 \\ 1"Al. I. Cuza" University, Faculty of Geography and Geology, Department of Geography, Iaşi, ROMANIA \\ 2 Romanian Space Agency, Bucharest, ROMANIA \\ 3 University of Bucharest, Faculty of Geography, Bucharest, ROMANIA
}

E-mail: ioana.vlad@rosa.ro, corneliu_iatu@yahoo.fr

DOI: 10.24193/JSSP.2017.2.05

https://doi.org/10.24193/JSSP.2017.2.05

K e y w o r d s: land use, change, urban area, in-situ, indicator, correlation, policy

\begin{abstract}
A B S T RACT
This article focuses on a specific dimension of environmental quality: land use and land cover, which experienced changes over time, having an important impact on biodiversity loss worldwide, causing soil and air pollution, altering local and regional hydrology. The main objective of this research was to review land use and land cover changes and to identify socio-demographic synergies in the urban area, by validating existing changes extracted from Earth Observation satellite data, provided by Corine Land Cover classes. To link these changes to statistical socio-demographic variables, we used the Pearson correlation coefficient and comparison tools. The study area was represented by the urban area in the South-East Danube Region. Results showed that there were classes that extended their territory, such as Galați, Brăila, Tulcea and classes that reduced their teritory such as forest, semi-natural and agricultural areas in almost all the analysed areas.
\end{abstract}

\section{INTRODUCTION}

The significance of land use and land cover changes dates back to prehistory representing both direct and indirect consequences of everyday human activities. First, this happened by burning areas to enhance the availability of wild games and then accelerated dramatically with the start of agriculture, resulting in excessive deforestation and the management of Earth's terrestrial surface that continues to this day [11]. More recently, urbanization has amplified due to industrialization, which determined the concentration of human population within urban areas and the depopulation of rural areas.

Land use and land cover changes are prevalent, while aggregated globally, and they affect key aspects of how Earth's systems function. They directly impact biodiversity loss worldwide, contribute to local and regional climate change [6], cause soil and air pollution, destroy the stratospheric ozone by nitrous oxide release from agricultural land and altered local and regional hydrology (dam construction, wetland drainage, increased impervious surfaces in urban areas). One of the most worrying and important issues on land cover changes is represented by the long-term threat to future food production due to the transformation of productive land for non-productive purposes, a conclusive example being that of changing the agricultural land into residential use. As a result of human activities, land cover changes during the last 300 years have been documented by several specialists. In 1864, George Perkins Marsh in his book "Man and Nature" described how landscape changed, resulting from human activities. Richards (1990) estimated that between 1950 and 1980 more forests were cut down than in the early $18^{\text {th }}$ and $19^{\text {th }}$ centuries combined [36]. 
In 1956, the book “Man's Role in Changing the Face of the Earth" reviewed the major changes in earth landscapes [39]. Lambin and Geist (2006) in their paper "Land use and Land cover Change-Local Processes and Global Impact" introduce the more recent books and programs, all reinforcing the idea that one of the most obvious global changes in the last three centuries has been the direct human conversion of land cover [23]. Here are mentioned books such as The Earth as Mapae Mundi, various reports of the World Resources Institute (People and Ecosystems: The Fraying Web of Life), the World Watch Institute (State of the World, 1996), the Millennium Ecosystem Assessment [23].

It is well known that land cover and land use are not the same. Land cover refers to the physical surface characteristics of land (for example, the presence of buildings in a determined area), while land use describes the economic and social functions of a specific area, outlined by the purposes for which humans exploit the land cover.

Land is a finite resource and the way it is used stands for the principal driver of environmental change, with significant impacts on the quality of life and ecosystems. Land use in Europe is influenced by important drivers, among which the increasing demand for living space per person, the interrelation between economic activities, the increased mobility from urban to rural areas and vice versa, the growth of urban infrastructure usually resulting in urban decline. Urban land takes over mostly agricultural land, but it also reduces space for ecosystems that provide important services like the regulation of water balance and protection against floods, mainly if soil is highly sealed [13].

According to the European Environment Agency, the annual land take in European countries assessed by 2006 Corine Land Cover project was of approximately $108,000 \mathrm{ha} /$ year in the period $2000-$ 2006. More arable land, permanent crops and fewer pastures were taken over by artificial development [14].

Apparently, the use of land always represents a correlation between various social, economic and environmental needs (such as housing, transport infrastructure, agriculture, and environmental protection), discussions in this area always reaching high decision forums, such as the European Commission. The Roadmap to a Resource Efficient Europe (EC) argues the fact that decisions on land use are made without an advanced analysis on the unexpected impacts [15]. By 2020, EU policies intend to take into account their direct and indirect impact on land use in the EU, as well as globally, and the rate of land take with an aim to achieve no net land take by 2050, given that spatial planning is essential to better reconcile land use with environmental concerns. Monitoring the negative environmental consequences of land use while sustaining the production of essential resources is a challenge that involves various policy levels.

In 1999, the European Spatial Development Perspective, prepared by the Committee on Spatial Development resulted in European policy orientations for territorial balance and cohesion, improved competitiveness, better management of natural resources, setting out objectives and guidelines for a balanced and sustainable spatial development [16].

Lately, integrated spatial development has been addressed by the Territorial Agenda of the EU that aims to provide strategic orientation for territorial development, fostering the integration of the territorial dimension within different policies at all governance levels, with a view to ensure the implementation of Europe 2020 Strategy according to territorial cohesion principles [17].

While considering all these legislative regulations, the detection, measurement and explanation of land use and land cover changes depend on the spatial and temporal level of analysis [2].

Technically, land cover changes are visible in remotely-sensed data or by providing evidence from statistics and in-situ measurements, such as agricultural census data. The temporal dimension of change is important because over long time periods, it can predict gradual changes of demographic and economic patterns.

A number of global and regional land cover mapping efforts using Earth Observation (EO) data from satellites have been undertaken over the past decade by utilizing sensors such as AVHRR, MODIS and SPOT Vegetation. A number of national and regional land cover data sets [9], including the National Land Cover Database (NLCD) for the USA, CORINE for Europe, and Africover for Eastern Africa, have been developed at $30 \mathrm{~m}$ resolution.

The CORINE (Co-ORdinated Information on the Environment) data series was created by the European Community as a means of collecting geospatial environmental information in a standardized and comparable manner across the European continent. CORINE is co-ordinated and partly-financed by the European Environment Agency under the Copernicus (formerly GMES) land monitoring programme.

Their objective was to facilitate the harmonization of environment state assessments in all EU countries, becoming a key data source for informing environmental and planning policies at local, regional and national level.

The CORINE land cover database provides support towards improving the quality and accuracy of spatial policies by using valuable remote sensing information in monitoring the uncontrolled urban development. In the past, information on land cover 
was available only for small areas affected by major infrastructure projects, by agricultural and urban development, relying on thematic information from topographic maps, which were updated every 10 to 15 years.

Against this background, including a wide range of environmental management purposes, the CORINE project provides support for cartographic as well as statistical assessments, advancing the possibility to reproduce the information at different scales to be useful at various decision-making levels. In the early 1990s, the Corine Land Cover project (CLC) was extended to include 13 Central and East European countries. The primary inputs were the Landsat TM image data recorded in the years 1986-1995.

The objectives of the Image and Corine Land Cover 2000 project were to provide a satellite image of Europe in 2000 and to update the Corine Land Cover map. Landsat 7 ETM+ was used, with image data recorded in 2000 and SPOT image data was also used for land cover mapping of coastal zones. The change dataset was integrated into the revised 1990 dataset to produce the 200025 ha 'update' dataset.

CLCL 2006 produced a revised version of the CLC 2000 dataset, a 2000-2006 5 ha change dataset and a new 25 ha CLCL 2006 dataset. The CLCL 2012 update includes three separate data products which provide significant improvements to the existing 2006 dataset: a revised 25 ha 2006 CORINE land cover dataset, a 5ha 2006-2012 CORINE land cover change dataset, the new CORINE 2012 25ha land cover dataset.

The purpose of this paper resides in proving the usefulness of employing the modern technology of satellite remote sensing to streamline the urban planning process, making it more effective and meaningful. Spatial planning provides an added dimension to statistical data validation analysis, which improves the visualization of the complex patterns and relationships that characterize real-world planning and policy issues.

The structure of the article introduces the general idea of urban policy implications for land use and land cover planning, issue argued in the research, which prompts a description of the materials and methods used for assessing the urban area in the SouthEast Danube region, continuing with discussions on the results achieved, concluding with the usefulness and advantages of using spatial and statistical indicators in providing valuable information for urban policies improvement.

\section{RESEARCH OBJECTIVE}

The main objective of this investigation is to analyse the nature and extent of land use/land cover changes and to identify the main socio-demographic synergies in the urban area.
The intention is to provide a better understanding of and improve our knowledge about the changing land use/land cover patterns and the impact of the environment on the quality of life, measured by correlating geo-information data to socio-demographic indicators.

The research aims to prove the hypothesis that the current annual increases within CLC urban classes are determined by several socio-demographic variables. Secondly, the objective of the research is to verify the benefits of satellite remote sensing monitoring, quantified by statistical data for urban policy update planning.

Assessing these environmental patterns could be useful to an urban policy implementation, which should provide a general framework to conduct public interventions in urban areas as a reference tool for public and political awareness of the achievements to be obtained from a sustainable urban development, as well as an opportunity to promote smart city territorial development.

Considering the United Nations Human Settlements Programme(UN-Habitat), the actuality and significance of developing such a land use/land cover urban policy is described by an urban development priority towards land use spatial configuration and environmentally friendly urban development.

\section{THEORY AND METHODOLOGY}

\subsection{Description of the study area}

Danube is the river with the highest number of bordering countries, having a large concentration of capital cities and metropolitan areas, which gives the Danube Region the potential for becoming one of the most dynamic, competitive and thriving macro-regions of the European Union in the $21^{\text {st }}$ century.

In accordance with the demanding issues of the EU Strategy for a prosperous Danube Region [18], this research focuses on environmental consideration analysis, building prosperity and strengthening the Romanian South-East Danube region by the improvement of urban policy significance following four time series of earth observation satellite data for identifying land cover changes.

The study area consists of eight urban areas of different sizes, located along the Danube River, coming across in four counties and having in common the Danube river, which borders each of the administrative units. Territorial information encompasses almost all relief forms: the Danube water meadow, the Bărăgan plain, the Dobrogea plateau with the Măcin Mountains, and the northwest side of the region comprises a part of the Carpathians and the Sub-Carpathians, the plain being the most preponderant morphological category. 
The highest perimeter area belongs to a small town, Sulina (14.16 sqm), harbour situated in the Tulcea district, Dobrogea area in the eastern side of Romania, the point where the Danube flows into the Black Sea. It is situated at the lowest medium altitude in our country, only 4 meters above the sea level, thus, more than a half of town territory being classified as wetland and water body. At a higher level above the sea, Tulcea, the first important harbour in the county with the same name, dates back to ancient times and it is an old town in the historical region of Dobrogea, located at the end of the second largest river in Europe, mainly covered by agricultural areas. Galați, an administrative area with a high impact for this research due to the significant land use and land cover changes registered between 1990 and 2012, is the capital town of Galați County, in the historical region of Moldavia, eastern Romania, the largest harbour on the Danube River, with the second highest share of territory (22\%), after Brăila with $29 \%$ of the urban territory within this area of interest (Fig. 1).

In the close vicinity of Galați we find Brăila, the capital of Brăila county. Măcin, Isaccea, Cernavodă, Hârșova with populations between 5,000 and 20,000 inhabitants represent the smallest administrative territories.

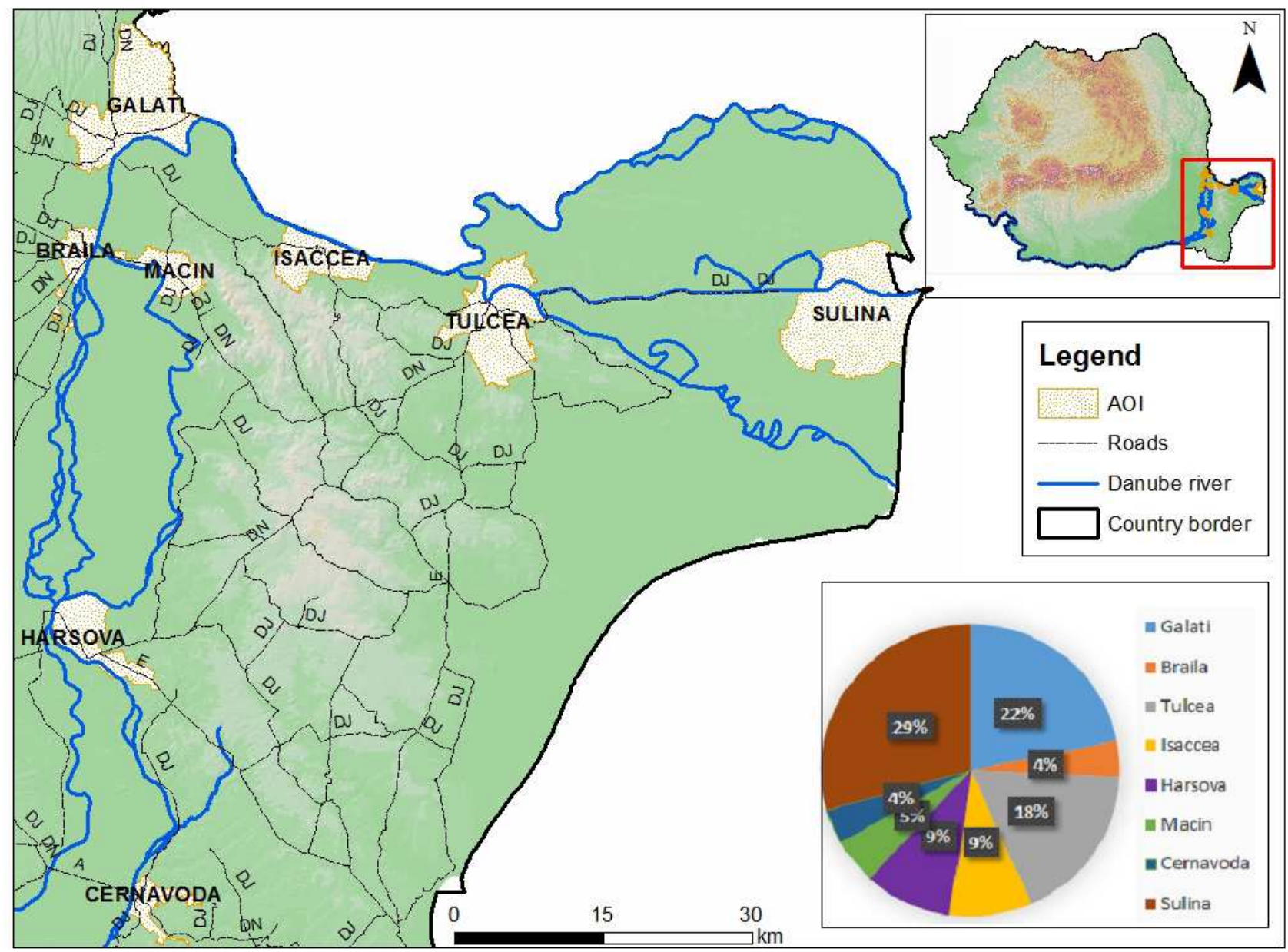

Fig. 1. Area of interest distribution in the South-East Development Region.

\subsection{Research method employed}

One fundamental tool of analysis applied here is comparison, playing a conclusive role in methodology development, bringing into focus suggestive similarities and contrasts between environmental components.

The research methodology used data reference until 2012, corresponding to the last published Corine Land Cover inventory.

The procedure first involved class area measurements in square kilometres for each CORINE level 1 data base: artificial surfaces, agricultural areas, forest and semi natural areas, wetlands and water bodies. The annual rate of change will be estimated as the difference between values registered in 2012 and 1990. The analysis is continued with Pearson correlation between CLC variables and sociodemographic statistical data, used for investigating the relationship between two quantitative, continuous variables, for example artificial surfaces extension and extended living area. The correlated variables are CLC classes: artificial surfaces, agricultural surfaces, forest and semi-natural areas and extended living area, private building extension, surface of green area (sqm) and number of households, human population growth, and average employees in agriculture. The general idea 
consists in demonstrating the domino effect of the above-mentioned indicators in triggering land cover changes.

\subsection{Indicators used}

Population is a driving force of environmental change, convenient to quantify using particular indicators, indicating the number of people that usually live in an area.

Population growth represents a fundamental indicator for national decision-makers, as one of the crucial factors affecting long-term sustainability, depending on the population size, birth rate, death rate, number of emigrants and immigrants. It exerts a strong pressure on land cover needs of resources, considering land a finite and a potentially productive natural resource, representing our basic food production facility. Thus, the intensive use of resources due to the increasing population, in conjunction with economic activities drive land use and land cover changes [37].

Extended living area (sqm), private building extension (sqm), number of households, average employees in agriculture, reveal the evolution of living in the urban area related to how the development investment plans are accomplished. Therefore, an extended living area and a positive population growth should justify the situation of extending artificial surfaces, based on the hypothesis that humans leave a mark on the environment, triggering economic, social implications at all scales, from global to local. The steep growth of population prompts the demand for places to live and work, which obviously increases the urbanization degree. Agricultural surfaces should be proportional with the average employees in this field of activity. The forest and semi-natural class within the urban area will be correlated with the green area surface.

\subsection{State of the art}

The planning of land use is considered an evaluation process useful for setting national priorities for developing urban planning policies. The concept of spatial planning was introduced in modernity, around 1970s-1980s, shifting from a product-oriented to a process-oriented activity [31]. Spatial planning is related to the economic development of counties, considering infrastructure, transportation, building constructions to determine sustainable land use management in urban regions. It is increasingly oriented towards being an instrument for analysing and resolving conflicting demands on space, aiming at looking at the spatial dimension of strategic urban policies.

The most representative Spatial Planning policies of the European Union are represented by the
European Spatial Development Perspectives (ESDP) (1999), Cohesion Policy 2014 - 2020 (2014), European Territorial Agenda 2020 (2011), which set the general conditions for land use policies with the help of strategies and instruments.

Urban growth and the concentration of people in urban areas are creating societal problems worldwide. Current literature identifies population growth as a dominant driving force of land use and land cover change [25], [1], [7]. Population decrease does not let to a decrease in built-up areas as many authors point out [26]. The reasons for this can be attributed to a decreasing household size and a rise in housing demand regardless of population decline. The evidence about the relationship between demographic changes and land use changes was comprehensively studied by researchers in University of Kiel [29] which aimed to investigate statistical relationship and spatial differentiations between demographic and land use change for Germany. A correlation was found between land use, natural population growth and migration, whereas for land use change in the shrinking regions in the East of Germany, economic variables are of noticeable importance.

Land use and land cover researchers often use remotely sensed data to provide information on resource inventory and land use to identify, monitor and quantify changing patterns in the landscape, population change and distribution being a significant driver of LULC in many regions of the world.

The state-of-the-art shows studies on the correlation of satellite and census data used to assess quality of life [24] to assess the effect of population change on forest cover in Ghana between 1990 and 2010, to understand change in agricultural activities in the Brazilian Amazon [5], to comprehend relationships between land cover and housing density in Wisconsin [34], to study land use and land cover changes and urban expansion in Greater Dhaka, Bangladesh, between 1975 and 2003 by using satellite images and socioeconomic data [10].

The most recent research [21] integrated land cover change data from Landsat TM images acquired in 1992 and 2007 and demographic data (from Latvian demographic censuses) at rural level in order to determine associations between LULC and demographic factors (population density and population growth).

\subsubsection{Urban policy amendment using spatial land use data}

Romania has to overcome all sorts of disparities after emerging from the communist era, while the European integration process speeded up change. As a consequence of the interrelation with current practices and policies developed in Western 
European countries, planning instruments, the legislative and administrative capacity have strengthened for managing the complex issues of urban environment.

According to EU regulations, Romania is divided into four NUTS 1 level divisions, eight development regions corresponding to NUTS 2 and 41 counties and the municipality of Bucharest corresponding to NUTS 3 [19].

The main legislation related to territorial and urban planning activities is the Territorial and Urban Planning Act (350/2001). Activities in this field are coordinated at national level by the government, which sets up priority programmes, guidelines and sector policies in relation to the content of the governing programme.

The National Strategy for Territorial Development Romania 2030 designs the sustainable integrated development of the Romanian territory, drawing up ways to take advantage of the national potential, to foster Romania's balanced development and to strengthen its role as a Member State of the European Union in a spatially integrated manner [32]. Obviously, we are aware of the existence of many other regulations and laws on urban policy planning, but it is not the scope of this article, as it is meant to introduce urban policy amendment and to agree on the validity of the method imposed.

The usage of spatial data could significantly improve urban policy-making and planning. This perception is strongly based on and supported by products derived from satellite data processing. As remote sensing satellites have provided more abundant land use information in the past ten years than at any other time in history, the analysis of satellite-detected urban land use has been recognized as the current mainstream approach to studying urban spatial patterns [45].

\section{RESULTS AND DISCUSSION}

\subsection{Land use change and population dynamics}

In CORINE Land Cover, the nomenclature covered three hierarchical levels: level 1 includes five very generic coverage themes (built-up areas, agriculture areas, forests, wetlands, water bodies), the second level is grouped in 15 groups and the third level is divided in 44 species. Results from the image processing revealed conceivable changes within land use classes spanning a period of 20 years of analysis, as detailed in table 1.

Table 1. Land cover change in square kilometres (sq m) from 1990 to 2012 in the South-East Development Region.

\begin{tabular}{|c|c|c|c|c|c|c|c|c|c|c|c|c|c|c|c|c|c|c|c|c|}
\hline \multirow[t]{2}{*}{$\mathrm{AOI}$} & \multicolumn{3}{|c|}{ Artificial s. } & \multirow[b]{2}{*}{2012} & \multicolumn{3}{|c|}{ Agricultural a. } & \multirow[b]{2}{*}{2012} & \multirow{2}{*}{1990} & \multicolumn{4}{|c|}{ Forest and semi natural a. } & \multicolumn{2}{|c|}{ Wetlands } & \multirow[b]{2}{*}{2012} & \multicolumn{3}{|c|}{ Water bodies } & \multirow[b]{2}{*}{2012} \\
\hline & 1990 & 2000 & 2006 & & 1990 & 2000 & 2006 & & & 2000 & 2006 & 2012 & 1990 & 2000 & 2006 & & 1990 & 2000 & 2006 & \\
\hline Galati & 43.64 & 49.02 & 49.68 & 47.31 & 153.24 & 144.87 & 143.23 & 148.39 & 13.8 & 12.2 & 13.14 & 11.16 & 5.71 & 4.74 & 4.74 & 7.66 & 30.44 & 35.29 & 35.28 & 31.65 \\
\hline Braila & 26.85 & 27.13 & 27.79 & 29.18 & 11.24 & 11.47 & 10.8 & 10.39 & 3.43 & 1.88 & 0.32 & 1.96 & 0 & 0 & 0 & 0 & 3.44 & 4.5 & 6.05 & 3.46 \\
\hline Sulina & 3.6 & 3.73 & 3.72 & 2.96 & 7.67 & 5.25 & 5.24 & 5.38 & 6.22 & 5.4 & 5.38 & 5.87 & 265.6 & 264.7 & 264 & 262 & 48.37 & 53.39 & 53.4 & 56.36 \\
\hline Macin & 3.58 & 4.73 & 4.73 & 4.3 & 41.24 & 41.38 & 41.43 & 40.71 & 9.56 & 8.66 & 8.58 & 9.49 & 0.66 & 0.36 & 0.36 & 0.36 & 1.21 & 1.1 & 1.12 & 1.39 \\
\hline Harsova & 4.74 & 4.45 & 4.52 & 4.1 & 80.67 & 80.15 & 79.37 & 80.22 & 14.79 & 15.87 & 16.31 & 14.96 & 0 & 0 & 0 & 0 & 6.36 & 6.11 & 6.33 & 7.3 \\
\hline Isaccea & 4.14 & 6 & 6.37 & 6.04 & 38.3 & 35.56 & 34.92 & 36.47 & 28.12 & 25.32 & 24.13 & 25.23 & 16.98 & 18.56 & 19.8 & 18.68 & 13.47 & 15.54 & 15.76 & 14.57 \\
\hline Cernavod & 4.47 & 5.37 & 5.62 & 7.36 & 26.32 & 29.56 & 28.71 & 27.47 & 8.66 & 4.61 & 5.18 & 4.94 & 0 & 0 & 0.19 & 0.3 & 4.13 & 3.85 & 3.85 & 3.5 \\
\hline Tulcea & 13.28 & 17.79 & 18.07 & 17.52 & 135.73 & 137.44 & 135.82 & 137.19 & 36.52 & 27.12 & 23.54 & 24.87 & 8.1 & 10.5 & 15.1 & 13.41 & 5.95 & 6.72 & 6.86 & 6.56 \\
\hline
\end{tabular}

Mostly, there was an increase in the area of artificial surfaces in this research; comparing the area of interest for the four CLC databases assessment, it appears that the highest artificial increase is in Tulcea, followed by Galați. In the first case, in 1990 it covered 13.28 square kilometres, to reach 18.07 square kilometres in 2006, with a slight decline to 17.52 in 2012.

Land take, known as urbanization or increase of artificial surfaces, represents an increase of settlements areas over time, process that is manifested as a process of expansion around an urban core, also known as urban sprawl, commonly used to describe physically expanding urban areas.

Tulcea has the largest agricultural areas with an annual rate of change of 1.46 sqm (Fig. 2). A different situation is seen in forest and semi-natural areas where the surface decreases, the annual rate of change in 2012 showing 11.65 sqm less than in 1990. The forested areas have an increasing coverage in Hârşova due to controlled forest cuts.

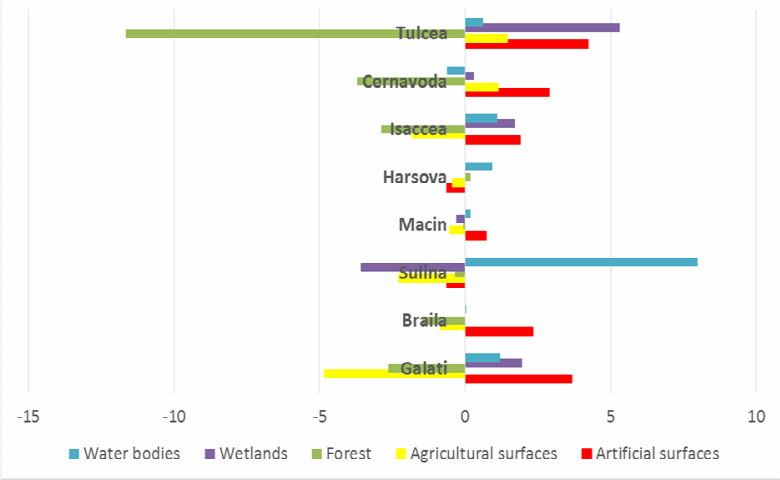

Fig. 2. Annual rate of land cover change for each AOI in South-East Region (2012-1990). 
The annual rate of change remains positive for the wetlands and the water bodies, mainly showing an increase in the area covered with water due to setting artificial lakes into the parks, bank erosion, and on the other hand because of choking the river course.

Land has a significant position in human existence and development, humans using land and their resources for material, social, cultural and spiritual needs. Human use of land, water and other natural and man-made resources is influenced by four major factors: population, economics, the environment and culture [8]. Human activities that make use of, changing or maintaining, attributes of land cover are considered to be one consequent source of change. The economic and social development affect the demand that will be placed on land, including institutions for ownership, incentives for land exploitation, markets or other institutions, labour force availability, sources and conditions of capital and credits.

Population size measured by number of people is not the only dimension of population that shapes land use. Other dimensions of population, such as the age structure, fertility, mortality and migration, human population growth, may also affect the consumption of vegetation and construction of buildings will change land use.

The latter variable represented by the living area extension indicator is analysed in this research; for quantifying changes in land cover with an ascending trend for each of the South-East urban areas, relevant improvements in the extended built up area are registered in Galați, Brăila and Tulcea, up to 0.426 sqm, between 2012 and 1990 (Fig. 3).

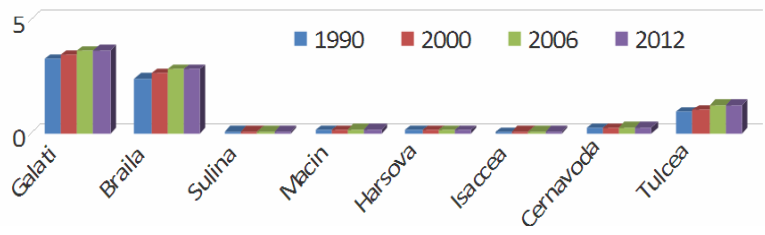

Fig. 3. The extension of the living area (sqm) in the South-East Danube urban areas

The population growth indicator sums up important characteristics of the demographic profile, nonetheless, it can be easily noticed that it does not influence land use changes in the area. A general negative trend can be distinguished during the period under scrutiny, with the highest negative growth rate registered in Galați, because of an important source of emigrants in 1990, when the new political and economic situation generated a feverish wave among the Romanian population, rediscovering the taste for democracy after almost half a century.

Hârşova and Cernavodă gave the example for a positive population growth rate between 1990 and 2012 through positive birth rates, low death rates and a number of emigrants which didn't influence in any way the human population growth rate.

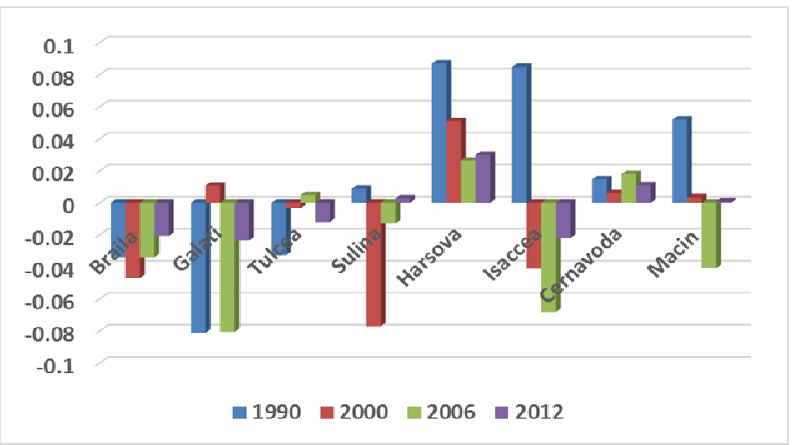

Fig. 4. Population growth rate evolution in the South-East Danube urban areas.

\subsection{Interaction between earth observation Corine Land Cover classes and statistical data - a basic support for urban policy management}

Urban policy management needs a regular review which could be emphasized by using both satellite data, which enables the repeated observation of any region on Earth, validated by statistical data as input sources, in order to establish reliable information services.

Such an analysis performed using Pearson correlation analysis indicates that the existing change in land cover presented databases could be linked to and validated by socio-demographic data. A bivariate correlation is pursued, used to determine if the involved EO data variables, artificial surfaces, forest and natural areas, agriculture surfaces are linearly related to extended living area, private building extension, green areas, household number, total natural growth, and the average number of employees in agriculture, for each delineated area of interest. The correlation of the mentioned variables should clarify our understanding on how population affects land cover changes. It is figured out between numerical variables, representing the rate of change for the period 2012 and 1990 for each indicator employed. One can see that the EO data variables intersection with each statistical data leads to a Pearson correlation coefficient, which is always represented by a value such $-1 \leq r \leq 1$, as mentioned in Table 2.

The Pearson correlation between artificial surfaces and extended living area is 0.706. This means that changes in one variable are correlated to changes in the second variable, and the output coefficient is higher than 0.50, which, according to Cohen's guidelines [8], creates a strong positive relationship between artificial surfaces and the extended living area. The positive correlation is given by the position trend of the two variables, which both increase in value as given in Fig. 5 B.

The negative correlation between agricultural surface and private building extension illustrates an increasing value of the first variable, the second variable decreasing in value, concluding that when the 
agricultural territory increases, the extended living area decreases. When combining the value for agriculture surfaces class with the average number of employees in agriculture, a week correlation is determined, $\mathrm{r}=0.143$, given by the sig (2-tailed) value, which is greater than 0.05, assuming that there is no statistically significant correlation between the two variables.

Table 2. Coefficient of determination for significant Pearson correlation to examine the relationship between land use/land cover EO data and socio-demographic statistical data, for the period 1990 and 2012.

\begin{tabular}{|c|c|c|c|c|c|c|c|}
\hline $\begin{array}{c}\text { EO data } \\
\text { variables }\end{array}$ & $\begin{array}{l}\text { Validation } \\
\text { method }\end{array}$ & $\begin{array}{c}\text { Extended } \\
\text { living } \\
\text { area }\end{array}$ & $\begin{array}{c}\text { Private } \\
\text { building } \\
\text { extension }\end{array}$ & $\begin{array}{l}\text { Green } \\
\text { area }\end{array}$ & Households & $\begin{array}{l}\text { Total pop. } \\
\text { growth }\end{array}$ & $\begin{array}{c}\text { Average } \\
\text { employees agric. }\end{array}$ \\
\hline \multirow{3}{*}{$\begin{array}{l}\text { Artificial } \\
\text { surfaces }\end{array}$} & $\begin{array}{l}\text { Pearson } \\
\text { Correlation }\end{array}$ & 0.706 & 0.447 & 0.150 & 0.631 & 0.687 & -0.562 \\
\hline & Sig.(2-tailed) & 0.050 & 0.267 & 0.722 & 0.093 & 0.060 & 0.147 \\
\hline & $\mathrm{N}$ & 8 & 8 & 8 & 8 & 8 & 8 \\
\hline \multirow{3}{*}{$\begin{array}{l}\text { Agricultural } \\
\text { surfaces }\end{array}$} & $\begin{array}{l}\text { Pearson } \\
\text { Correlation }\end{array}$ & -0.083 & -0.750 & 0.114 & 0.381 & -0.131 & 0.143 \\
\hline & Sig.(2-tailed) & 0.844 & 0.032 & 0.788 & 0.352 & 0.758 & 0.753 \\
\hline & $\mathrm{N}$ & 8 & 8 & 8 & 8 & 8 & 8 \\
\hline \multirow{3}{*}{$\begin{array}{l}\text { Forest and } \\
\text { semi-natural } \\
\text { areas }\end{array}$} & $\begin{array}{l}\text { Pearson } \\
\text { Correlation }\end{array}$ & -0.425 & 0.028 & -0.168 & -0.972 & -0.453 & 0.191 \\
\hline & Sig.(2-tailed) & 0.289 & 0.948 & 0.690 & 0.001 & 0.260 & 0.651 \\
\hline & $\mathrm{N}$ & 8 & 8 & 8 & 8 & 8 & 8 \\
\hline
\end{tabular}

Differently from this, there is the correlation between artificial surfaces and extended living area, which has a statistically significant correlation, the sig. value being equal to 0.05. This value is most often exceeded for the correlation between artificial surfaces and total population growth, showing a weak correlation between the two variables.

$\mathrm{N}$ (Table 2) stands for the number of samples analysed, at each of the eight South-East Danube towns.

A different situation is experienced when trying to correlate the forest natural area variable to the green area extension (Fig. 5D), Pearson's $r$ is negative, as the variables involved weren't at all correlated.

As one can observe in Figure 5, the output correlated variables were represented by scatterplots, which can tell the meaning of the relationship between variables, the same way Pearson's $r$ does, determining the strength and direction of the relationship between variables, indicating a positive, negative or zero correlation. SPSS gives the equation of the line that best describes all the points.

According to Evans (1996), correlation is an effect dimension and the strength of the correlation can be described following the correlation guide for the absolute value of $\mathrm{r}$ : 0.00 - 0.19 "very weak", 0.20 - 0.39 "weak", 0.40 - 0.59 "moderate", 0.60 - 0.79 "strong", $0.80-1.0$ "very strong" [12]. A strong correlation is represented by the reasoning that an increasing population growth rate and the extended living area prove a valid extension of the artificial surfaces (Fig. 5 A, B). An example of a weak correlation reflects in a reduction of agricultural surfaces, during the analysed period, and the average number of employees in agriculture, based on a decreasing trend of both variables.

The correlation between forest surfaces and green areas proves to be negative as the statistical variable is measured just for the inside of the urban area and the EO data variable coverage includes information both for the inside and outside of the urban area.

In the absence of human growth phenomena, however, we are witnessing an extension of the artificial surfaces, strongly correlated with the extension of the living area, referring to continuous and discontinuous housing and also industrial, commercial and transport units, which developed in the last 20 years. Even if the total population growth registered mainly negative values, the real investments were highly intensified, supported by governmental programs.

The Romanian government launched this economic program six years ago as an incentive to boost the housing market. Under the scheme, first-time buyers can take out a credit from a private bank to purchase a residence at an attractive interest rate.

The state guaranteed loans of up to 60,000 Euros for an older apartment, 70,000 Euros for a new one and up to 75,00o Euros for those who want to build their own homes, thus allowing access to mortgage loans to many people who otherwise couldn't qualify.

The National Loan Guarantee Fund manages such a program, meant to relaunch the economy, develop the business economy, create and maintain new jobs, functioning as a joint stock company with the Romanian state as the single shareholder. Based on this economic opportunity, more and more business 
developers raised commercial buildings meant to answer population needs, both for office spaces, events,
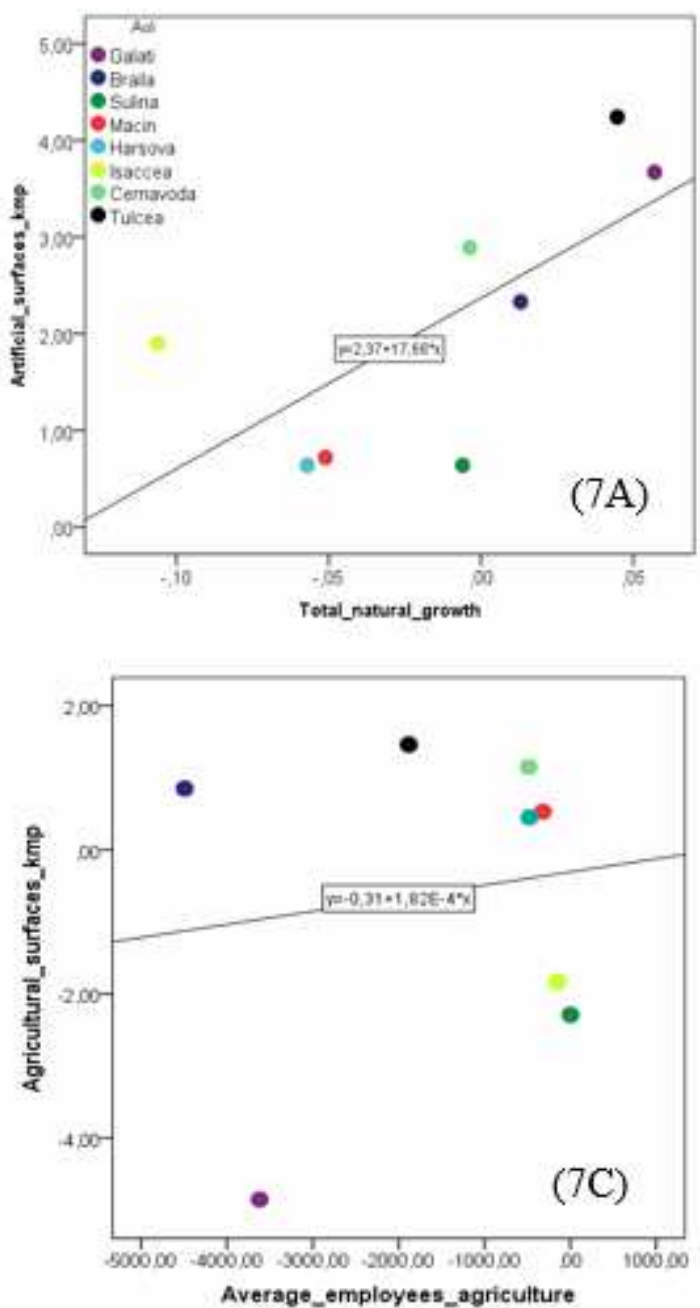

ballrooms, shopping, and retail galleries and for residential purposes.
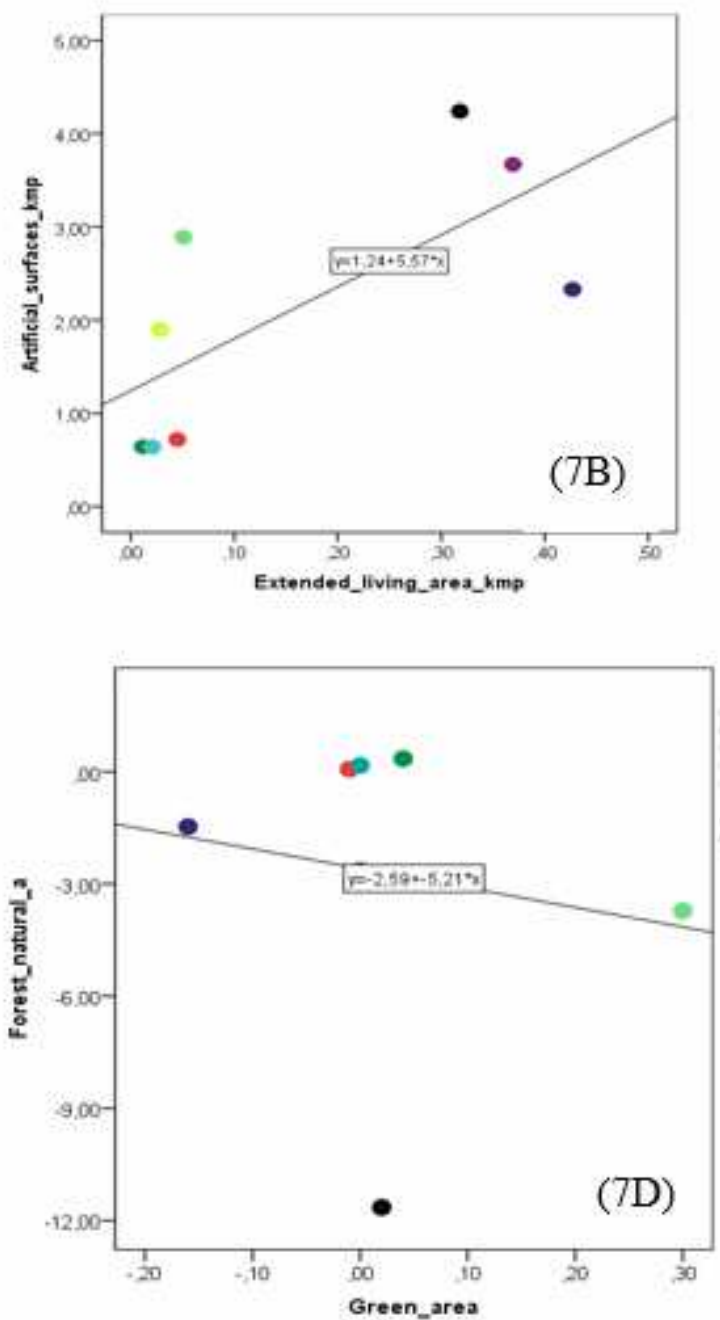

Fig. 5. Scatterplots description of the significant Pearson coefficient.

\section{CONCLUSIONS}

The results from this study revealed changes within the analysed land cover/land use urban territories, assessed by using remote sensing techniques and statistical data. As such, it used the essential source consisting in European land monitoring data, CORINE land cover inventory, carried out in 1990, 2000, 2006 and most recently in 2012, a database highly promoted by the COPERNICUS program, which strengthen the European capacity for earth observation and facilitate more frequent analysis of land use changes in Europe as a basis for future policymaking.

The objective of this study was to examine the identified spatial changes of the main categories of land cover, artificial surfaces, agricultural areas, forest and semi-natural areas that have occurred in the South-East Danube towns and to investigate the correlation with socio-demographic statistics.

Using the comparative method, classes were identified that extended their territory, similar to
Galați, Brăila, Tulcea in artificial surfaces and water bodies or on the contrary, reduced areas were identified in terms of forest, semi-natural areas and agricultural surfaces in almost all the areas of interest assessed here. As for giving evidence on the EO data recording for land use/land cover issues, correlations were made for the first three of the five level CLC classes with sociodemographic statistical data, as population growth, extended living area, average employees in agriculture and inside urban territory, by using Pearson's coefficient. This methodology was able to create an urban capacity building method for detecting and reporting land use change as a critical issue in evaluating and monitoring trends in the effectiveness of public investment in natural resource management. The involvement of models and historic data to predict past, present and future land use changes based on specific input data and statistical correlation may help identify key drivers of land use change, implement scenario planning and fill gaps in data availability which contribute to an accurate urban extent appraisal. 
Land cover changes represent a valuable indicator for proving the annual urban increases or decreases over time. The benefits of considering and become aware of changes in land cover/land use data should become more and more helpful for public authorities. The better management of land resources is essential for sustainability and for improving quality of life in cities and towns, as one of the keys to meeting commitments on several international obligations for climate change and biodiversity. Accurate, timely, accessible and up-to-date information on new housing and industrial/commercial developments can be routinely provided from satellite observation in support of regional and municipal planners' decision on policy and spatial planning.

\section{AKNOWLEDGEMENTS}

This work was supported by POSDRU project 159/1.5/S/133391 in Romania, co-financed through Sectorial Operational Program for the Development of Human Resources 2007 - 2013 from European Social Fund.

\section{REFERENCES}

[1] Axinn, W., Ghimire, D. (2011), Social Organization, Population and Land Use, Population Studies Centre Research Report. American Journal of Sociology 117, no. 1 (July 2011): 209-258. https://doi.org/10.1086/661072

[2] Briassoulis, H. (2009), Factors Influencing Land Use and Land Cover Change in Land Use, Land Cover and Soil Sciences, Vol. I. Encyclopedia of Life Support Systems (EOLSS). Available online at: http://citeseerx.ist.psu.edu/viewdoc/download?doi=10 .1.1.598.365o\&rep=rep1\&type $=$ pdf

[3] Brown, T, McLafferty, Sarah, Moon, G. (2010), A Companion to Health and Medical Geography, Wiley-Blackwell. Available online at: https://zodml.org/sites/default/files/A_Companion_to _Health_and_Medical_Geography.pdf

[4] Brown L. R. (1996), A worldwatch Institute Report on Progress towards a Sustainable Society, Worldwatch Institute, Washington, DC, USA.

[5] Cardille, J. A., Foley, J. A. (2003), Agricultural land use change in Brazilian Amazonia between 1990 and 1995: evidence from integrated satellite ad census data. Remote Sensing of Environment, 87(4), pp. 551562. https://doi.org/10.1016/j.rse.2002.09.001

[6] Chase, T. N., Pielke, R. A., Kittel, T. G. F., Nemani, R. R., Running, S. W. (1999), Simulated impacts of historical land cover changes on global climate in northern winter. Climate Dynamics (2000) 16: 93-105. https://doi.org/10.1007/s003820050007.

[7] Codjoe, S. N. (2004), Population and land use and land cover dynamics in the Volta River basin of Ghana. Ecology and Development Series, No. 15, Cuvillier Verlag, Gottingen.
[8] Cohen, J. (1988), Statistical power analysis for the behaviour sciences ( $2^{\text {nd }}$ edition), Hillsdale, N. J. Erlbaum, Joyner library.

[9] *** Committee on Spatial Development (1999), European Spatial Development Perspective. Towards Balanced and Sustainable Development of the Territory of the European Union, Office for Official Publications of the European Communities, Luxembourg.

[10] Dewan, A. M., Yamaguchi, Y. (2009), Land use land cover change in greater Dhaka, Bangladesh using remote sensing to promote sustainable urbanization, Applied Geography 29(3), pp. 390-401.

[11] Ellis, E. (2013), Land use and land cover change, The Encyclopaedia of Earth.

[12] Evans, J. D. (1996), Straightforward statistics for the behavioural sciences. Pacific Grove, CA: Brooks/Cole Publishing.

[13] *** European Environment Agency (2016), Urban sprawl in Europe, no 11, Copenhagen

[14] *** European Environment Agency (2007), CLC 2006 technical guidelines, no 17, Copenhagen.

[15] *** European Commission (2011), Roadmap to a Resource Efficient Europe, Communication from the Commission to the European Parliament, The Council, The European Economic and Social Committee and the Committee of the Regions, COM. 571, Brussels

[16] *** European Communities (1999), European Spatial Development Perspective. Towards balanced and Sustainable Development of the Territory of the European Union, European Commission, Luxembourg

[17] ** European Commission (2015), Territorial Agenda 2020 put in practice, Enhancing the efficiency and effectiveness of Cohesion Policy by a place-based approach, vol. II, Centre for Industrial Studies, Directorate-General for Regional and Urban Policy, Brussels.

[18] *** European Union (2011), The EU Strategy for the Danube Region, Panorama Inforegio, vol. 37, Brussels.

[19] EUROSTAT (2011), Regions in the European Union - Nomenclature of territorial units for statistics NUTS 2010/EU-27, Publication office of the European Union, Luxembourg

[20] Finifter, A. (1993), Political science: The State of Discipline II, Washington, D.C., American Political Science Association.

[21] Fonji, S. F., Taff, G. (2014), Using satellite data to monitor land use land cover change in Northeastern Latvia, Springer Plus, 3:61.

[22] Goudsblom, J., Vries, B. (2002), Mappae Mundi, Humans and their habitats in a long term Socio-ecological Perspective, Amsterdam University Press, pp. $21-46$.

[23] Lambin, E. F., Geist, H. J., Lepers, E. (2003), Dynamics of land use and cover change in tropical and subtropical regions. Annu Rev Env Resour 28, pp. 205241.

[24] Lo, C. P., Faber, B. J. (1997), Integration of Landsat thematic mapper and census data for quality 
of life assessment. Remote Sensing Environment 62(2), pp. 143-157.

[25] Marsh, G. P. (1864), Man and nature, or physical geography as modified by human action. Harvard University Press, Cambridge (reprint edition; edited by David Lowenthal 1965).

[26] Mateoc, N., Mateoc, T., Manescu, C., Grad, I. (2014), Analysis of the phenomenon of population's migration in Romania, Scientific Papers, Series Management, Economic Engineering in Agriculture and Rural Development, vol. 14, Issue 1, ISSN 2284-7995.

[27] Meade, S., Emch, M. (2010), Medical Geography, Guilford Publication Press.

[28] Moore, D., Carpenter, T. (1999), Spatial analytical Methods and Geographic Information Systems: Use in Health Research and Epidemiology, Epidemiologic Reviews, vol. 21, no. 2.

[29] Muller, B., Kilper, H. (2005), Demographic change in Germany - challenge for sustainable spatial development, Geographische Rundschau, 57 (3) (2005), pp. 36-41.

[30] Munteanu, C., et al (2014), Forest and agricultural land change in the Carpathian region $-A$ meta-analysis of long term patterns and drivers of change, Land use policy, vol.38, pp. 685-697.

[31] *** World Resources Institute (2005), Millennium Ecosystem Assessment, Ecosystems and Human Well-being: Synthesis. Island Press, Washington, DC. Available online at: https://www.millenniumassessment.org/documents/d ocument.356.aspx.pdf

[32] *** (2008), Strategic Concept of Territorial Development. Romania 203o. Ministry of Development, Public Works and Housing, Directorate General for Strategies and Policies for Territorial Cohesion

[33] Okeke, D. (2015), Spatial Planning As Basis For Guiding Sustainable Land Use Management. WIT Transactions on State-of-the-art in Science and Engineering.

[34] Radeloff, V. C., Hagen, A. E., Voss, P. R., Maldenoff, D. J. (2000), Exploring the spatial relationship between census and land cover data. Society and Natural Resources, 13(6), pp. 599-6o9.

[35] Richardson, W. H., Chang Woon Nam (n.d), Shrinking Cities - A global perspective, Routledge Taylor and Francis Group.
[36] Richards, J. F. (1990), Land transformation. In: Turner, B. L. II, Clark, W. C., Kates, R. W., Richards, J. F, Mathews, J. T., Meyer, W. B. (eds) The Earth as transformed by human action: Global and regional changes in the biosphere over the past 300 years. Cambridge University Press, Cambridge, pp. 163-178

[37] Sahalu, G. (2014), Analysis of land use and land cover changes, Instituto Superior de Estatistica e Gestao de Informacao (ISEGI), Universidade Nova de Lisboa, Lisbon, Portugal.

[38] Serneels, S., Lambin, E.F. (2001), Proximate causes of land use change in Narok District, Kenya: a spatial statistical model. Agric. Ecosyst. Environ. 85, 65-81

[39] Thomas, W. L. Jr. (ed) (1956), Man's role in changing the face of the Earth. Chicago University Press, Chicago, p. 1193.

[40] *** United Nations (1993), Agenda 21: the United Nations programme of action from Rio. New York: United Nations.

[41] Verburg, P. H., de Koning, G. H. J., Kok, K., Veldkamp, A., Bouma, J. (1999), A spatial explicit allocation procedure for modelling the pattern of land use change based upon actual land use. Ecol. Model. $116,45^{-61 .}$

[42] Wang, Y., Zhang, X. (2001), A dynamic modelling approach to simulating socioeconomic effects on landscape changes. Ecol. Model. 140, 141162.

[43] *** WHO (1993), Global Strategy: Health, Environment and Development: Approaches to Drafting Country-wide Strategies for Human Wellbeing under Agenda 21. Geneva: WHO.

[44] *** World Resources Institute, World Bank Group (2000), World Resources: People and Ecosystems: The Fraying Web of Life, Elsevier Science

[45] Hao Wu, Yurong Sun, Wenzhong Shi, Xiaoling Chen, Dongiie Fu (2013), Examining the Satellite-Detected Urban Land Use Spatial Patterns Using Multidimensional Fractal Dimension Indices, in Remote Sensing 2013, 5, 5152-5172. DOI: 10.3390/rs5105152.

[46] Wu Jun Jie (2008), Land Use Changes: Economic, Social, and Environmental Impacts, Choices, 4 ${ }^{\text {th }}$ Quarter 2008, 23(4). Agricultural and Applied Economics Assiciation. Available online at: http://www.choicesmagazine.org/UserFiles/file/article -49.pdf 